\title{
On Necessity of Philosophics - Scientific Study of Philosophy
}

\author{
By Vasily Vasilievich Markhinin*
}

\begin{abstract}
The paper outlines and grounds the research program of the problem of specific essence of philosophy. Solution to the problem of the reconstruction of the essence of philosophy sets a special goal and singles out a special object domain, which means that there must be a special scientific subdiscipline of the History of Philosophy. We suggested naming this philosophical science philosophics. In the subject sphere of philosophics the research hypothesis of what the essence of philosophy is, must allow the formation of empirical basis from the texts, identified as the archetypal philosophical texts. Firstly, it is the texts, where the meaning of the ancient Greek word-

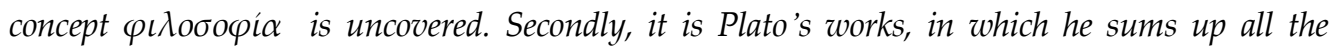

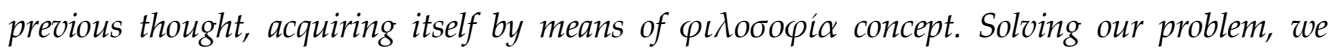
should read the corresponding groups of texts as mutually complementary.
\end{abstract}

Nay more, should some recondite subject need Fresh signs to make it clear to those who read, A power of issuing terms till now unused, If claimed with modesty, is never refused.

New words will find acceptance, if they flow Forth from the Greek, with just a twist or so.

Horace (Art of Poetry, $48-53$.

J. Conington's translation)

\section{Relevance of the Concept of Philosophy per se}

Philosophy in our times is, by its social renomé, beholden to science and to the system of higher education, in which philosophical subjects are mandatory. In other words, it is largely beholden to science, given that the modern educational system is geared to the reproduction of scientific knowledge. A significant portion of the public directly takes philosophy for, so to say, a "real" science (as if the positivistic reform has completely succeeded) or considers philosophy to be "the science of sciences" (as if Hegel's point of view has been completely exonerated). The official channels of modern states, while sanctioning a venerable social status of philosophy, predominantly imply a representation as the philosophy of science but also a function of the methodology of science.

\footnotetext{
${ }^{*}$ Professor, Surgut State University, Russia.
} 
The question, among the philosophers and philosophical experts of modern times (i.e., the twentieth and twenty-first centuries), arises evermore frequently: What is philosophy, after all? Given the fact that this question is so persistently repeated, we can sense the pathos with which it is subtly expressed, in the style of Plato: What is philosophy per se? The subtlety of this question derives from its timeliness: Philosophy cannot be solvent as the philosophy of science or in the function of methodology of science unless it is solvent as philosophy per se in its specific essence.

\section{Problem and Task of the Research}

The complexity of the question thus discussed is not proved by the absence of an answer. On the contrary, the fact that multiple answers have been found and continue to multiply is a testament to the complexity of the question. Each individual who poses this question finds an answer to it, but each answer is unique. The generally valid meaning of such answers is not made clear, and that forces us to acknowledge the unsatisfactory condition of the question's historiography. The examination of philosophical process indicates that the preserved ambiguity of the generally valid meaning in the exegesis of the essence of philosophy - which appears as the result of goaloriented discourse - only reproduces general provisions in philosophy when every philosopher, whether he gives an account or not regarding his vision of the essence of philosophy, always implies such a picture corresponding to his particular philosophical system.

It is obvious that the generally valid meaning of the essence of philosophy is implemented one way or another in the historical and philosophical process, and this is true in the modern context as well. How can this generally valid meaning be reconstructed? Apparently, it cannot be revealed by comparing the visions of philosophy by those whom the tradition refers to participants of the philosophical process. It is, however, evident that the comparison of a large number of particular positions, as intended to define their common meaning, cannot produce an acceptable result. In the best-case scenario, we will receive an abstract-common definition reminiscent of a household term, known and accepted before any special research and lying outside the limits of the subject matter in which we are interested. Let us say that hardly anyone would argue that the generally valid definition of philosophy is the definition of this science as a theoretical form of the word "cognition." However, our question as a research problem begins at the point from which we must come to the realization of what the word is, as an object of namely philosophical cognition, and what the specifics of this cognitive activity are. 
Consequently, the generally valid meaning of the specific essence of philosophy is implemented not in the abstract-common contents of its particular vision but in the compliance with a certain other principle. Of course, that principle is confined in the essence of the philosophy. It is clear that if we seriously accept the thought that not every image (nor all particular images) of philosophy deserve to be invoked with respect to the elucidation of the essence of philosophy but only such an image deserves this treatment, in which the essence of philosophy has been embodied as an exemplar, we would then not even have a thought in order to solve our task of following the dead-end path that reveals the abstract-common contents of omnifarious doctrines, which refer to the class of philosophical ones. Because this thought is not accepted, a vicious circle of logic becomes inevitable: In order to clarify the essence of philosophy we must rely on the principle, in accordance with which the essence of philosophy is implemented in the philosophical process, but the essence of philosophy is the question we must resolve. However, the discovery of the given vicious circle of logic is already beneficial for our purposes, because with it one realizes that the tradition and accepted opinions (as well as the conceits) do not guarantee the accuracy of personal and chronotopic outlines of the philosophical process. Images of philosophy, accepted by the tradition and opinion, are also particular in the sense that the quality of specifically philosophical cognition is implemented in them to various degrees, to the point of having a complete lack of such quality.

\section{Ambiguous Treatment of Ancient Philosophy}

Incidentally, in this regard it should be noted that we of the present epoch are extremely persistent in our questions about the essence of philosophy. Thus we begin to realize, even admit, that it does not clearly illustrate the state of modern philosophy. We see, for example, that those who are involved in philosophy presume that modern philosophy can - according to various philosophers and experts, based on its scientific nature - be a more perfect method of philosophical cognition than was available to those of previous epochs. Notably, the conviction of superiority of modern philosophy over the earlier one coexists with the assumption that philosophy degrades, following the path of its abolishment as a science, as predicted in the nineteenth century. ${ }^{1}$

Those directly or implicitly accepted assumptions do not, in our opinion, allow one to properly admit and assess the value for the clarification of the question of philosophy, since it is essentially the truth that philosophy during

1. Ken Baynes, James Bohman, \& Timothy McCarthy, After Philosophy: End or Transformation? (Cambridge and Massachusetts: The MIT Press, 1987). 
all times remains itself to the extent that it remains faithful to its Ancient Greek example. The acknowledgment by the philosophers of the "new" and "newest" times of the exemplary aspect of Ancient Greek philosophy is confirmed by their need to address the antique heritage. However, the presumption of superiority, justified by the fact that this particular doctrine, they say, most satisfactorily expresses the spirit of the modern époque and "finally" answers to its demands, whereby the Ancient Greek philosophy is discredited as an exemplary form of philosophism. In lieu of addressing the Ancient Greek example, the resolution of the question of what philosophy is, is given on the grounds of this or that particular philosophical doctrine.

\section{Turn of the Newest Era and its Inconsistency}

It should be emphasized that the matter does not stand any differently. We are not talking only about particular solutions to this or that philosophical problem but about the fact that certain problems entail the creation of a new, unique solution, according to the conviction of each of the philosophers of a truly exemplary example of the philosophy in general. For example, E. Kant, having placed at the center of the philosophical problematic the subject of cognition, has classified the ontological objects as ostensibilities of a certain kind and assessed his doctrine as a "Copernican revolution in philosophy," thus making it clear that the previous philosophy and, first of all, antique philosophy, is a backward form of knowledge; something like Ptolemean astronomy in comparison to Copernican astronomy. Henceforth, the exemplary philosophy is philosophy, in his case being centered on an epistemological subject. I.G. Fichte, having proposed his "epistemology" (Wissenschatslehre), stated that it provides a truly scientific (absolutely exact, strictly subordinated, systematic, etc.) knowledge, and the adopted prerequisites (cognizing "me" as the manifestation of the absolute "me") are so new that no other philosophy (including antique philosophy, one must assume) is in principle not capable of this "absolutely new discretion." According to Hegel, the Ancient Greek philosophy is just a naïve initial stage of philosophism, constituting an instant of philosophical thought in the epoch concluded by him; a true philosophy, congruent with the science as the absolute knowledge, in light of which only special scientific knowledge is meaningful.

Auguste Comte, promulgating his doctrine as the embodiment of an overdue epoch's call to transform the philosophy into science, generally treats the Ancient Greek philosophy as a retrograde one for metaphysics (ontology), which it contains. Therefore, the image of true philosophy, according to Comte, is his philosophy project, from which metaphysics (ontology) is removed. By the beginning of the twentieth century, the Comtean program of transforming philosophy into science had failed; it failed even in light of post- 
Comtean positivism. In the "second positivism" and neo-positivism, a new program for the creation of a philosophy of science had been proposed as a replacement for Comte's program. The truth is that, despite this and after the thought about the necessity and possibility of transforming philosophy into science, albeit on different grounds than those of positivism, remains relevant from the perspectives of certain philosophical minds. E. Husserl's conception is extremely well known, in which he seeks to turn philosophy into a "strict science" by adding phenomenological procedures to its arsenal (epoché, phenomenological reduction, etc.). Again, the declared revolution in philosophy is accompanied by the qualification of ancient philosophy as inadequate to the cognitive tasks of the truth about "things themselves."

However, in all probability it was the failure of the Comtean program of transforming philosophy into science - the program that, in the nineteenth century, encouraged the extreme popularity of positivism in philosophical and scientific circles - had a decisive value as the stage from which the specifics of philosophy were recognized as being special and fundamentally different than the scientific cognitive type. What was not evident, not only for the nineteenth century and for Comte and positivists but also for nearly all the philosophers of the new era, was that the philosophy and the science were nearly always intermixed in the terminological and contextual sense. Now, during the newest era, many philosophers who are related to various directions and sects - including L. Wittgenstein, A. Bergson, M. Heidegger, K. Jaspers, H. G. Gadamer and others - have concluded that philosophy and science, although interrelated, are nevertheless different, special kinds of cognitive activity, providing knowledge about the world, the validity of which has different status.

The understanding of the fact that philosophy is specific and independent in relation to the scientific cognition type should have contributed to the establishment of a consistently fundamental line in accepting antique philosophy as an exemplar; the primordial and specific historical form of philosophy that, by its genesis and existence, demonstrates its independence, needless to say its dependence, from the science. It means this should have contributed to the understanding that the fundamental initial value for clarification of the essence of philosophy has the same image, which was initially created in the culture of Ancient Greece. This expectation, however, has not yet been justified until today. Moreover, it seems, for the very same reason--due to the existing presumption that the modern point of view is superior to that of the historical past, the justification for which is a certain philosophical Ego, with its specific responsiveness to the demands of the appropriate contemporary epoch. 


\section{Example of Martin Heidegger}

Martin Heidegger's position is extremely illustrative in this regard. His philosophical creativity is characterized by the conviction that modern philosophy's need to address its Ancient Greek heritage cannot be satisfied only concurrently for the resolution of certain tasks as excursions into antique origins: We must realize the essence of philosophy as manifested in Ancient Greek philosophism, wherefore the essence of philosophy is presented, namely in Ancient Greek philosophy. In his article titled Was ist das - die Philosophie? Heidegger emphasizes that the path to understanding the essence of philosophy started with the understanding of the meaning of Ancient

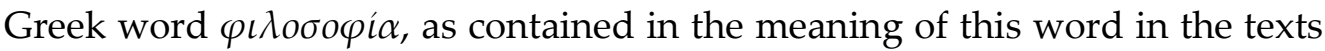
of Ancient Greek philosophers. ${ }^{2}$ In reality, Heidegger does not so much read the interpretation of the essence of philosophy in Ancient Greek texts but "imposes" it in them. In fact, Heidegger concludes that philosophy is the understanding of the essence of being of substance, although the Greeks did not discriminate between being and substance, as Heidegger rightly has noted in other works. ${ }^{3,4}$ The delineation between being and substance is the central point of the philosophical doctrine of Heidegger, and ultimately he had to adapt to his understanding the interpretation of the essence of philosophy in general, as it was presented in Ancient Greek philosophism.

Heidegger, at the same time, discredits the Ancient Greek philosophy. The main thought of his "fundamental ontology" consists of assigning to the Greek philosophy the responsibility for substituting being with substance or transforming ontology into metaphysics (which, to him, is the same thing).

2. Martin Heidegger, Was ist das - die Philosophie? (What is it - the philosophy?) (Pfullingen: Günter Neske, 1956).

3. __ "Der europäische Nihilismus" ("The European nihilism"), in Nietzsche M. Heidegger, Gesamtausgabe. Band 6.2, 23-256 (Frankfurt am Main: Vittorio Klostermann $\mathrm{GmbH}$, 1997).

4. Here, in particular Heidegger (_ "Der europäische Nihilismus," 222-223) notes: "<... in various concepts of apriority, achieved within separate metaphysical positions, in proportion to their interpretation of being $<\ldots>$ lies the roadmap for closer delineation of the role, that the difference between Being and Substance plays, although it had never been contemplated as such." (emphasis added - V. M.) With complete definitiveness the same circumstance is noted by N. Hartmann, the author of one of the most significant ontological studies of the newest times. Hartmann writes: "The ancient did not clearly realize the difference between ov from $\varepsilon v v \alpha \mathrm{l}$, although the language gave it to their disposal, and did not conduct any research in this sphere. This refers already to Parmenides, but not to a lesser degree to Plato and Aristotle" (Nicolai Hartmann, "Sein and Seiendes. Formaler Sinn der Grundfrage" ("Being and beings. Formal sense of the basic question") Zur Grundlegung der Ontologie (Berlin: Walter De Gruyter \& Co., 1965), 37). 
This, according to Heidegger, crosses out not only the possibility of thinking about being but also entails the degradation of philosophical thinking. The same, as he considers it, had predetermined the scientific and technical development path of European civilization, leading to a consumptive attitude toward being, and then to consumption, destruction, oblivion of being under the form of substance, undermining the foundations of genuinely human existence. This is why the compelling need of modern thinking, which aspires to become philosophical thinking again, consists, according to Heidegger, of returning to the sources of philosophical thought but only in the name of ontologically oriented pre-Socratic thinkers. He considers the doctrines of Heraclitus and Parmenides to be the highest achievement of philosophical thought, which had advanced alternative interpretations of being, respectively, as absolutely mobile and absolutely motionless. In that regard, he particularly values the doctrine of Parmenides - for posing the problem of truly being or of the truth about being. At the same time, according to Heidegger, ${ }^{5}$ the task consists of overcoming metaphysics, which he believes was founded by Plato, who shaped the pre-Socratic philosopher's ontology into a metaphysical form. ${ }^{6}$ Allegedly, Plato was the first metaphysicist and therefore supposedly subversive with regard to the meanings of philosophy and civilization, in which the state of affairs in Ancient Greek philosophy is interpreted by Heidegger.

Philosophy, regardless of the condition by which it would act in this or that epoch, would surely play an important role in the destiny of European (and global, during the newest era) civilization. It should be noted that, in our opinion, to place the responsibility for the crisis of anthropological foundations of modern European civilization on the aforementioned shift in the Ancient Greek philosophy, even if this shift is evaluated in the same way as Heidegger does, means to imbue this shift with extraordinary meaning; to see in it something like the original sin of European mankind, for which, during our time, it is afflicted as the divine scourge. We are inclined to consider that, generally and overall, those are civilizational shifts that define the shifts in the state of philosophy, not vice versa.

We, however, cannot decisively agree with Heidegger's assessment of this shift in Ancient Greek philosophy, which occurred during the transition from pre-Socratic philosophers to that of Plato. By distinguishing ontology

5. Martin Heidegger, "Platons Lehre von der Wahrheit (Plato's doctrine of truth) (1931/32, 1940)" in Martin Heidegger, I. Abteilung: veröffentlichte Schriften 1914-1970. Gesamtausgabe. Band 9, 203-239 (Frankfurt am Main: Vittorio Klostermann GmbH, 1976).

6. In general, more information about Heidegger's interpretation of Ancient Greek philosophy in the context of his Fundamental ontology can be found in Akhutin (Anatoly Valerianovich Akhutin, Antique Origins of Philosophy (St. Petersburg: Nauka, 2007), 150-170. [In Russian].) 
and metaphysics in such a way that the latter is the theory of a structured, somewhat organized world in which the being (as embodied in the existent being) is lost, shedding its indefinitely multifarious potentials, Heidegger would seek to de-incarnate metaphysics into ontology, considering that truly philosophical reflection is the reflection about the being of substance instead of reflection about the substance as incarnated being. That is, it is assumed that true philosophism is ultimately reflection about "pure" being; of being before it becomes world. "To think out being without substance," according to Heidegger, is "to think out being without looking back at metaphysics."7 Heidegger suggests that this is because the world, as the universe that became ordered, is substance due to its distinction from being. However, if together with Heidegger we would consider that allegedly "unlike metaphysics the question of philosophy does not consist of reflecting whether the world is set up correctly and, accordingly, how to think correctly about the world" but instead in "how being is possible, how truth is possible,"8 whether we could expect a philosophical answer to such a question, not even speaking about the answer, could we pretend it to be true? This is why no single philosopher, whether Heidegger nor anyone else who later raised this question, has even tried to answer the question: How is being possible? It is obvious just because this question in principle cannot have a rationally articulated answer. There are things about which nothing intelligible could be said and, as L. Wittgenstein remarked, it is better to keep silent about, at least from the standpoint of a philosopher. Heidegger calls us to listen to the "voice of being," which comes from the rubble of substance. Maybe "pure being" whispers certain news about itself; about its "possibility." However, to listen to what is rationally incommunicable - the occupation of a mystic, poet or wizard but not a philosopher, as is clear from those generally accepted definitions of philosophy - cannot be attributed to the problematic interpretations of its essence.

Ancient Greek philosophers, we would think, did not discern being and substance in the sense that $\mathrm{M}$. Heidegger deems necessary, nor did they reflect on "pure" being, i.e., certain impossible "being before and without substance." In other words, they did not reflect on what cannot be subjected to rational reflection. The Greek philosophers reflected on being as the world of substance or as creation; the universe, arising and established as an ordered universe. Even if it is so, the statement that Plato had, for the first time, created a metaphysical doctrine, which transformed the ontologies of his predecessors, is true only in that his doctrine - metaphysical or, in other

7. Martin Heidegger, "Zeit und Sein (Time and Being) (1962)" in Martin Heidegger, Zur Sache des Denkens (To the point of thinking) Gesamtausgabe. Band 14, 5-30 (Frankfurt am Main: Vittorio Klostermann GmbH, 2007), 5-6.

8. Akhutin, Antique Origins of Philosophy, 673. 
words, ontological - for the first time systematically and entirely dismissed in itself the ontological or, in other words, metaphysical research of all anterior philosophical thought, or, in fact, whether the said Parmenides was searching for some "pure" being or an answer to the question on how it was "possible." No, he, like any of the pre-Socratic philosophers, was building an author's model of the world; a universe arranged in a certain way.

Consequently, the work of $\mathrm{M}$. Heidegger shows that even such a philosopher, who tends to preserve the link with the ancient philosophy as an example of philosophism and makes an invaluable contribution to the interpretation of this sample, like many other philosophers, cannot avoid denigrating the antique example and substituting it with that particular interpretation of the essence of philosophy that corresponds to his own particular doctrine.

\section{Can We Understand what Philosophy Is from the Position of Metaphilosophy?}

We should note that philosophers, in point of fact, are usually convinced that the true interpretation of the essence of philosophy may be only its interpretation by philosophers, i.e., by philosophism. In the case of Heidegger, it goes without saying. The purpose of the question, "What is philosophy?" he says, is to "enter philosophy, settle in it and act in accordance with it," i.e., engage in "philosophism." 9 However, why should the question about the essence of philosophy should be solved in any way other than philosophism? It is Heidegger himself who remarks: "The question, "What is philosophy?" is not one of those questions that directs the cognition of a certain kind on itself (the philosophy of philosophy)."10 However, is not engaging in philosophism in order to comprehend the essence of already established philosophy - Ancient Greek philosophy - means taking the metaphilosophical position (the position of "philosophy of philosophy")? Aren't the attempts to resolve the question about the essence of already historically established philosophy through philosophism - the attempts that copy the most incredible adventure of Baron Munchausen, as when he pulls himself up by his own hair - the reason for substituting the Ancient Greek image of philosophy with the image that is presumed by one's very own special philosophical doctrine of a given "me," engaged in philosophism?

Additionally, Heidegger notes that the question about the essence of philosophy calls forth the need to address the history of Ancient Greek origins of philosophy. "The word "philosophy," emphasizes the philosopher, if we hear it

9. Heidegger, Was ist das - die Philosophie?, 3-4.

10. Ibid., 10. 
correctly and reflect on what we have heard, calls us into the history of the Greek origins of philosophy."11 The history, in our case is the history of Ancient Greek philosophy. This, first of all, is the subject of historical research. In modern society, it is the subject of the history of philosophy as a science. However, the author would shortly disavow the noted message, obviously because this message does not respond to the strategy of solving the question uniquely through philosophism. The question about the essence of philosophy, dogmatically and without comments or arguments, is, according to Heidegger, "not also a question of history, interested in how what is called "philosophy" originated and developed."12

\section{Necessity of Philosophics, the Science about Philosophy}

It follows from the above statement that the strategy of solving the question about the essence of philosophy only through philosophism, excluding the necessity of a scientific, historical and philosophical approach, is one that cannot be argued convincingly. For example, one could not deem convincing the following argument, which consists of the assumption the philosophical understanding of Ancient Greek texts is a co-philosophism of a certain kind with their authors, and, as they say, it is adequate to the task of understanding the essence of philosophy as it is its vision from within the philosophical context, while the scientific and objective research is not adequate to this task, due to the fact that they would be "alien" to this matter. ${ }^{13}$ However, we presume that the "co-philosophism" in particular resorts to substitutions, taking the place of the archetypical antique understanding of the essence of philosophy, particularly as it is understood by one or more modern authors, that such "co-philosophism" is in fact a quasi-dialogue. The antique philosophers did not have the possibility of clarifying their position, nor could they object to authors of later eras. Consequently, they could not prevent arbitrary interpretations of their positions. Because the materials of antique philosophers exist only in the form of their texts, meaning in the objectified form, the proper interpretation of their materials requires that we are guided, first and foremost, by the principle of objectivity. The historian of philosophy, whose research is guided by a scientific and objective approach, may not necessarily be and is usually not a philosopher (i.e., the creator of his own philosophical doctrine), but neither is he "alien" in philosophy, since he is capable of understanding and has the culture of

11. Ibid., 8.

12. Ibid., 10.

13. Akhutin, Antique Origins of Philosophy, 61-62. 
interpretation of already existing philosophical doctrines. This, in fact, is necessary in order to solve the task in question.

It should be emphasized that the position we state is in no way a rejection of the value of "co-philosophism" of modern philosophers with the philosophers of antiquity, particularly as a way to reconstruct and reproduce the essence of philosophy in the philosophical process. In our opinion, it is important to understand that this method of reconstruction and reproduction of the archetypal example of philosophism, in terms of the overall historical and philosophical process, is the reproduction of the given example in various forms. In terms of this or that separate doctrine, it is a development method of the given doctrine. However, this does not cancel out the increasing timeliness (as noted above) of understanding the essence of the philosophy in its generally valid meaning; a meaning that is implemented in diverse forms in separate philosophical doctrines and sects, regardless of how it is interpreted by separate philosophers and how adequately they implement it in their creative works. The understanding of this is a scientific task.

From the moment the science became a fundamental fact of the public life, we found we could not count on the possibility that the philosophy would be "independent from science," just as we could no longer count on "being free from society." The problem of philosophy is not in its connection to science but only in the character of this connection, which brings down philosophy's mission to be the "servant of science." This connection is for the benefit of philosophy. It has been noted that the very same circumstances that cause a problem create the means for its resolution. The new era, having given birth to the tendency to subordinate philosophy to science, created the conditions for the science - the history of philosophy - to become an efficient, non-philosophical cognition tool for philosophy's realization of its essence as an independent, special kind of cognitive activity.

In this regard we share the approach, according to which, in order to solve the resolution of the theoretical in its essential question about what is philosophy, it is ultimately necessary to address "the corresponding empirical material, the facts," namely artifacts - i.e., the facts - which in this case result from the spiritual activity of people ... . "The products of this aspect of man's vital activity have validity, regardless of whether someone wants to accept them or does not want and whether he makes them an object of his attention or does not want to do so. If those products have been objectified or, in our case, embodied in philosophical texts, they form an area of special activity that is susceptible to empirical assertion and empirical research."14

It is obvious that we are talking about the necessity of scientific research regarding the question of what philosophy is.

14. Vasily Pavlovich Goran, "Philosophy: What is it?" Philosophy of Science 1, no. 2 (1996): 3. [In Russian]. 
It is true that until the methodology of research in philosophy is formulated in such a general form that does not go beyond the requirement to be based on empirics in the form of philosophical texts, it is the methodology of scientific research of philosophical process in general, i.e., the methodology of the history of philosophy as a science. However, the scientific research, however, of what the philosophy is as such presumes the need to single out a special subject sphere in the history of philosophy as a science. This is not to say that every text, empirically stated as philosophical may be a reliable element of the empirical basis for the research of the essence of philosophy. The complexity in this case, as shown above, consists of defining what texts, being related from the traditions to the rank of philosophical ones, are representative from the standpoint of legitimacy as means to solve the question of the essence of philosophy by their interpretation in objective and generally valid meaning. The scientific research of what philosophy is in essence should be based on the empirical foundations of texts, being recognized as archetypal philosophical texts; that is, as texts, where the initial and eternally valid example of philosophism is presented. We had the opportunity to publish the consideration about the necessity to form such special historical and philosophical discipline, and we propose to call this science about philosophy philosophics. ${ }^{15}$

\section{Conclusion}

The antecedent analysis allows us to outline the following base points in the array of texts, representing an archetypal image of philosophy. First of all, these are texts that reveal an entire world of meaning of the Ancient Greek

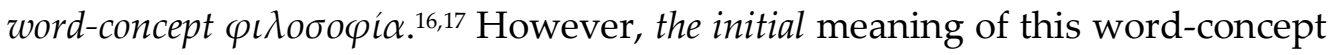
for the formation of philosophy and, respectively, for the understanding of its essence was stated, as previously stated, by M. Heidegger. He started the work of reconstructing the meaning of this word. However, besides the notes on his research position, as stated above, we must add that Heidegger, coming closer to the reconstruction of the meaning of the Ancient Greek word $\varphi \iota \lambda о \sigma o \varphi i \alpha$, takes into account only the context of the proper philosophical word usage. Moreover, the philosophical word usage implicitly implies those meanings of words that comprise the word $\varphi \iota \lambda o \sigma o \varphi i \alpha$, which were functioning in the context of a mythological world view. Without explaining

15. Vasily Vasilievich Markhinin, "Philosophics - the Science of Philosophy" Philosophy of Science 2 (2007): 173-176. [In Russian].

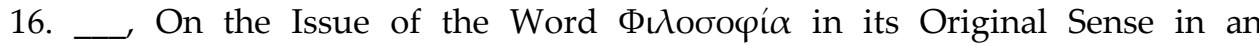
Anthology of Philosophical Studies. Ed. Patricia Hanna 5 (2011).

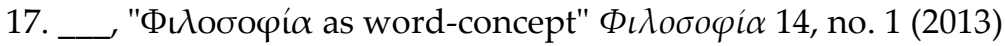




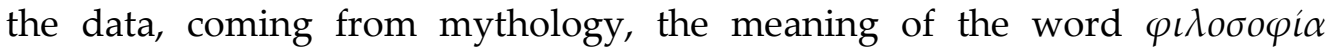
remains significantly incomplete and not sufficiently clear. First of all, these, contrary to M. Heidegger and his followers - are Plato's texts, in which Plato, summarizing the antecedent thought that materialized itself with the

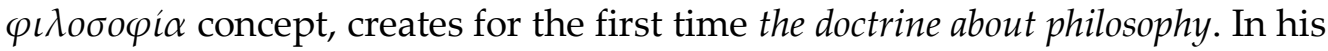
study, philosophy comes to the awareness of itself, thus completing its establishment and self-determination. That is how this doctrine about philosophy was created for the first time and has a generally valid meaning. However, we must admit that, from this perspective, Plato's heritage has not been sufficiently researched. The problem here, we think, consists of taking the key to the Plato's doctrine about philosophy as it was exactly the implied

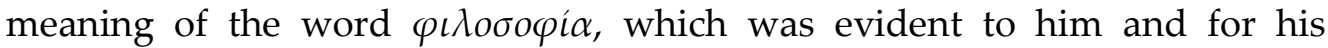
philosophizing coevals. This meaning, being rooted in mythology and "wisdom," is not quite clear to us. Moreover, it will not become clear unless, besides everything else, it is read from the position of Plato's doctrine. This is why, when solving our task, we have to read the corresponding groups of texts as mutually complementary.

\section{Bibliography}

Akhutin, Anatoly Valerianovich. Antique Origins of Philosophy. St. Petersburg: Nauka, 2007. [In Russian]

Baynes, Ken, Bohman, James, \& McCarthy, Timothy. After Philosophy: End or Transformation?. Cambridge and Massachusetts: The MIT Press, 1987.

Goran, Vasily Pavlovich. "Philosophy: What is it?" Philosophy of Science 1, no. 2 (1996): 3-14. [In Russian].

Hartmann, Nicolai. "Sein and Seiendes. Formaler Sinn der Grundfrage" ("Being and beings. Formal sense of the basic question"). Zur Grundlegung der Ontologie. Berlin: Walter De Gruyter \& Co., 1965.

Heidegger, Martin. Was ist das - die Philosophie? (What is it - the philosophy?). Pfullingen: Günter Neske, 1956.

. "Platons Lehre von der Wahrheit (Plato's doctrine of truth) (1931/32, 1940)." In M. Heidegger, I. Abteilung: veröffentlichte Schriften 1914-1970. Gesamtausgabe. Band 9, 203-239. Frankfurt am Main: Vittorio Klostermann $\mathrm{GmbH}, 1976$.

"Der europäische Nihilismus" ("The European nihilism"). In Nietzsche M. Heidegger, Gesamtausgabe. Band 6.2, 23-256. Frankfurt am Main: Vittorio Klostermann GmbH, 1997.

. "Zeit und Sein (Time and Being) (1962)." In Martin Heidegger, Zur Sache des Denkens (To the point of thinking) Gesamtausgabe. Band 14, 5-30. Frankfurt am Main: Vittorio Klostermann GmbH, 2007. 
Markhinin, Vasily Vasilievich. "Philosophics - the Science of Philosophy." Philosophy of Science 2 (2007): 173-176. [In Russian]

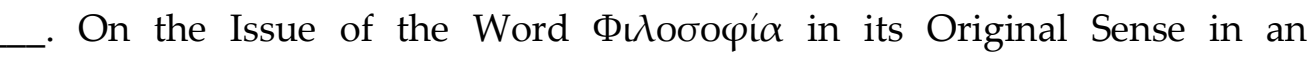
Anthology of Philosophical Studies. Ed. Patricia Hanna 5 (2011): 87-96.

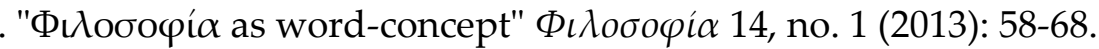

